\title{
Studi Timbulan Dan Reduksi Sampah Rumah Kompos Serta Perhitungan Emisi Gas Rumah Kaca Di Surabaya Timur
}

\author{
Amar Addinsyah dan Welly Herumurti \\ Teknik Lingkungan, Fakultas Teknik Sipil dan Perencanaan, \\ Institut Teknologi Sepuluh Nopember (ITS) \\ Jl. Arief Rahman Hakim, Surabaya 60111 Indonesia \\ e-mail: herumurti@enviro.its.ac.id
}

\begin{abstract}
Abstrak- Wilayah Surabaya Timur juga merupakan wilayah yang memiliki jumlah unit rumah kompos terbanyak di Surabaya yaitu sebanyak delapan unit rumah kompos. Unit rumah kompos tersebut mendapat pasokan sampah yang kebanyakan berasal dari perantingan dan sampah pasar. Pada unit rumah kompos tersebut belum terdapat suatu metode pengendalian terhadap emisi gas rumah kaca yang dihasilkan dari proses pengomposan. Penelitian ini bertujuan untuk menentukan timbulan sampah, kemampuan reduksi, dan emisi gas rumah kaca pada rumah kompos di Surabaya Timur.

Metode yang digunakan dalam studi ini adalah metode perhitungan timbulan dan komposisi sampah menurut SNI 193964-1994. Sedangkan untuk perhitungan emisi gas rumah kaca digunakan metode perhitungan menurut IPCC Guideline for National Greenhouse Gas Inventories. Penelitian ini melibatkan tiga skenario. Skenario pertama merupakan skenario rumah kompos Surabaya Timur dengan delapan rumah kompos dan dua unit gasifikasi berfungsi serentak. Skenario kedua merupakan skenario dengan lima rumah kompos dan dua unit gasifiaksi berfungsi serentak. Skenario ketiga merupakan skenario tanpa reduksi sampah dan sampah langsung dikirim ke TPA.

Hasil dari penelitian timbulan sampah yang masuk di rumah kompos Surabaya Timur meliputi $51487,11 \mathrm{~kg}$ per bulan untuk sampah daun, 76654,04 kg per bulan untuk sampah kayu, dan $26778,13 \mathrm{~kg}$ per bulan untuk sampah pasar. Hasil penelitian tingkat reduksi menyatakan tingkat reduksi sebesar 50,74\% untuk skenario pertama perhitungan dan tingkat reduksi sebesar $34,68 \%$ untuk perhitungan skenario kedua. Hasil penelitian emisi gas rumah kaca menyatakan emisi gas rumah kaca sebesar $5,80 \mathrm{Gg} \mathrm{CO}_{2}$ per bulan untuk skenario pertama, emisi gas rumah kaca sebesar 5,13 Gg $\mathrm{CO}_{2}$ per bulan untuk skenario kedua, dan emisi gas rumah kaca sebesar $0,49 \mathrm{Gg} \mathrm{CO}_{2}$ per bulan untuk skenario ketiga.
\end{abstract}

Kata Kunci-Gas Rumah Kaca, IPCC, Kompos, Rumah Kompos.

\section{PENDAHULUAN}

$\mathrm{S}$ AMPAH adalah bahan sisa, baik bahan-bahan yang sudah tidak digunakan lagi (barang bekas) maupun bahan yang sudah diambil bagian utamanya yang dari segi ekonomis, sampah adalah bahan buangan yang tidak ada harganya dan dari segi lingkungan, sampah adalah bahan buangan yang tidak berguna dan banyak menimbulkan masalah pencemaran dan gangguan pada kelestarian lingkungan [1]. Pemerintah Kota
Surabaya memiliki 18 rumah kompos yang tersebar di seluruh Surabaya untuk melakukan pengomposan sampah organik. Rumah kompos memanfaatkan sampah pasar, sampah taman, sampah jalanan, dan sampah pemukiman sebagai bahan dalam pembuatan kompos. Kegiatan pengomposan dapat mengurangi volume sampah 50-85\%. Dari 18 rumah kompos yang dimiliki Kota Surabaya, delapan diantaranya berada di wilayah Surabaya Timur. Kegiatan pengomposan yang dilakukan di rumah kompos Surabaya Timur menggunakan metode pengomposan windrow composting. Kegiatan pengomposan yang dilakukan secara windrow composting akan menghasilkan gas metan $\left(\mathrm{CH}_{4}\right)$. Dalam kondisi pengomposan secara anaerob maupun aerob juga akan menghasilkan karbon dioksida $\left(\mathrm{CO}_{2}\right)$. Gas ini merupakan kontributor utama dari emisi global [3]. $\mathrm{CO}_{2}$ dan $\mathrm{CH}_{4}$ merupakan gas rumah kaca (GRK) yang merupakan kontributor utama pemanasan global.. Gas $\mathrm{CO}_{2}$ merupakan salah satu emisi gas rumah kaca (GRK) yang potensial [4]. Peningkatan GRK dapat menyebabkan suhu di permukaan bumi semakin tinggi. Oleh karena itu, pengelolaan sampah dengan metode pengomposan mulai mendapat banyak perhatian guna menanggulangi dampak negatif yang mungkin ditimbulkan dari proses pengomposan [5].

Dari uraian tersebut di atas maka diperlukan suatu studi tentang timbulan dan komposisi sampah yang masuk ke rumah kompos serta tingkat reduksi yang mampu dicapai oleh rumah kompos dan emisi gas rumah kaca yang dihasilkan di Surabaya Timur.

\section{METODE PENELITIAN}

Penelitian ini melibatkan tiga skenario. Skenario pertama merupakan skenario rumah kompos Surabaya Timur dengan delapan rumah kompos dan dua unit gasifikasi berfungsi serentak. Skenario kedua merupakan skenario dengan lima rumah kompos dan dua unit gasifiaksi berfungsi serentak. Tiga rumah kompos yang tidak difungsikan adalah rumah kompos Liponsos, rumah kompos Wonorejo, dan rumah kompos Srikana. Skenario ketiga merupakan skenario tanpa reduksi sampah dimana sampah langsung dikirim ke TPA. 


\section{A. Pengumpulan Data}

\section{Kuisioner}

Kuisioner bertujuan untuk mengetahui wilayah pelayanan, jam operasional, teknik pengomposan, alat-alat pengomposan, serta jenis dan jumlah alat pengangkut. Kuisioner berupa essai, dimana responden dapat langsung menjawab dan mengisikan pendapatnya pada lembar kuisioner. Pengisian kuisioner dilakukan dengan teknik wawancara dan pengisian langsung. Kuisioner diberikan kepada pengelola rumah kompos di Surabaya Timur.

\section{Data Survey Rumah Kompos}

Data sampling diperoleh dari pengambilan sampel di rumah kompos selama 8 hari. Pengukuran dan perhitungan sampel timbulan dan komposisi sampah mengacu pada SNI 19-39641994 tentang metode pengambilan dan pengukuran sampel timbulan dan komposisi sampah perkotaan. Survey dilakukan di rumah kompos Bratang.

- Jumlah timbulan sampah

Pengukuran jumlah timbulan dilakukan selama 8 hari. Pada pengukuran timbulan sampah digunakan satuan volume basah (m3/hari) dan berat basah (kg/hari). Pengukuran jumlah timbulan dilaksanakan dengan cara menimbang setiap sampah yang masuk ke rumah kompos.

- Komposisi sampah

Perhitungan komposisi sampah dilakukan setelah pengukuran jumlah timbulan sampah. Sampah yang telah diukur timbulannya kemudian dipilah sesuai jenisnya kemudian ditimbang dan dicatat berat sampah untuk setiap jenisnya. Jenis sampah yang dipilah antara lain kayu/ranting, daun, dan sampah organik lainnya.

- Kapasitas dan jenis alat pengelola sampah

Data kapasitas dan jenis alat pengelola sampah didapatkan melalui wawancara kepada petugas pengelola rumah kompos. Selain itu juga dilakukan survey langsung ke area rumah kompos.

- Area pelayanan dan frekuensi pengumpulan sampah

Pengumpulan data area pelayanan dan frekuensi pengumpulan dilakukan di masing-masing rumah kompos. Pengumpulan data melalui wawancara kepada petugas pengelola rumah kompos.

\section{B. Analisis dan Pembahasan}

Data yang terkumpul kemudian diolah untuk menjawab rumusan masalah dengan penjelasan sebagai berikut:

\section{Analisis timbulan sampah}

Analisis timbulan sampah dilakukan selama 8 hari, setelah data jumlah sampah terkumpul dilakukan perhitungan timbulan sampah menurut SNI 19-3964-1994 tentang Metode Pengambilan dan Pengukuran Sampel Timbulan dan Komposisi Sampah Perkotaan sebagai berikut.

$$
\text { Timbulan }\left(\frac{\mathrm{kg}}{\text { org. hari }}\right)=\frac{\text { berat sampah }\left(\frac{\mathrm{kg}}{\text { hari }}\right)}{\text { jumlah orang (org) }}
$$

\section{Analisis komposisi sampah}

Berdasarkan data pengukuran jumlah dan jenis sampah, selanjutnya dilakukan analisis komposisi sampah yang mengacu pada SNI 19-3964-1994 tentang Metode Pengambilan dan Pengukuran Sampel Timbulan dan Komposisi Sampah Perkotaan.

$\%$ komposisi sampa $h_{\mathrm{i}}=\frac{\text { berat sampa } h_{\mathrm{i}}(\mathrm{kg})}{\text { berat sampah total }(\mathrm{kg})} \times 100 \%$

\section{Analisis reduksi sampah}

Reduksi sampah merupakan sampah yang dapat direduksi di rumah kompos. Reduksi sampah dapat diketahui dari jenis dan jumlah sampah yang masuk ke rumah sampah dalam jangka waktu tertentu. Untuk memperoleh jumlah sampah tereduksi pada pengelolaan sampah di rumah kompos, data timbulan dan komposisi sampah yang telah diperoleh sebelumnya diolah terlebih ke dalam bentuk material balance. Material balance yang disusun meliputi data sebagai berikut:

- Jumlah sampah yang masuk ke rumah kompos

- Jumlah sampah yang diolah dalam proses pengomposan

- Jumlah sampah yang diolah melalui pembakaran

- Jumlah sampah yang tidak terkelola

Dari selisih jumlah sampah yang masuk dan jumlah sampah yang tidak terkelola maka akan diperoleh jumlah sampah yang tereduksi.

$$
\% \text { Reduksi }=\frac{\text { berat sampah tereduksi }(\mathrm{kg})}{\text { berat sampah total }(\mathrm{kg})} \times 100 \%
$$

\section{Perhitungan emisi gas rumah kaca}

Perhitungan emisi GRK dilakukan secara manual menggunakan MS Office Excel dan diinterpretasikan dalam bentuk grafik maupun angka dengan satuan $\mathrm{Gg} /$ tahun. Emisi GRK yang diestimasi adalah emisi karbon dioksida, $\mathrm{CH}_{4}$, dan $\mathrm{N}_{2} \mathrm{O}$.

\section{HASIL DAN PEMBAHASAN}

\section{A. Volume dan Timbulan Sampah}

Pengukuran volume dilakukan dengan cara mengukur kapasitas alat pengangkut sampah yang masuk ke rumah kompos kemudian dikalikan dengan banyaknya alat pengangkut yang masuk ke rumah kompos. Hasil dari pengukuran volume kemudian dikalikan dengan densitas yang diperoleh dari hasil pengukuran.

Hasil pengukuran densitas sampah yang masuk ke rumah kompos Bratang diperoleh hasil rata-rata densitas sebesar $92,51 \mathrm{~kg} / \mathrm{m} 3$ untuk sampah hasil perantingan dan 261,25 $\mathrm{kg} / \mathrm{m} 3$ untuk sampah pasar. Untuk komposisi sampah pemilahan hanya dilakukan pada sampah hasil perantingan dengan cara memotong dan memisahkan bagian daun dari batangnya. Dari hasil pengukuran diperoleh komposisi ratarata sebesar $40,18 \%$ untuk sampah daun dan $59,82 \%$ untuk sampah kayu. Untuk sampah pasar tidak dilakukan pemilahan karena sampah pasar yang masuk sudah terpilah dan sudah tercacah sehingga siap digunakan sebagai bahan baku 
pembuatan kompos.

Dari hasil perhitungan volume dan densitas sampah, diperoleh besar timbulan sampah. Besarnya timbulan sampah di rumah kompos Surabaya Timur dapat dilihat pada tabel 1. Dari hasil perhitungan dapat diketahui bahwa rumah kompos di Surabaya Timur menggunakan ranting dari hasil perantingan dan sampah pasar sebagai bahan baku pembuatan kompos.

Tabel 1.

Timbulan Sampah di Rumah Kompos Surabaya Timur

\begin{tabular}{lrrc}
\hline \multicolumn{1}{c}{ Rumah Kompos } & Daun (kg) & Kayu (kg) & $\begin{array}{c}\text { Sampah } \\
\text { Pasar (kg) }\end{array}$ \\
\hline Bratang & 6824,9 & 10160,9 & 15933,6 \\
Menur & 6199,3 & 9229,5 & 7709,5 \\
Rungkut Asri & 11238,5 & 16731,9 & - \\
Tenggilis Utara & 1045,6 & 1556,7 & - \\
Tenggilis R. Taman & 4136,7 & 6158,7 & - \\
Wonorejo & 16875,4 & 25124,1 & - \\
Liponsos & 4088,8 & 6087,3 & - \\
Srikana & 1077,9 & 1604,8 & 3135,0 \\
Total & 51487,1 & 76654,0 & 26778,1 \\
\hline \hline
\end{tabular}

Diantara delapan rumah kompos di Surabaya Timur hanya rumah kompos Bratang, rumah kompos Menur, dan rumah kompos Srikana yang menerima sampah pasar sebagai bahan baku.

\section{B. Penyusutan Kompos}

Penyusutan pada komposter terjadi karena selama proses pengomposan berlangsung terjadi degradasi sampah oleh mikroorganisme menjadi gas. Besarnya penyusutan pada kompos ini diukur dengan cara menghitung selisih tinggi windrow pada awal pengomposan dan tinggi windrow pada saat kompos telah matang. Tinggi windrow pada awal pengomposan diambil dari windrow yang usianya paling muda. Sedangkan tinggi windrow pada saat kompos telah matang diambil dengan mengukur tinggi windrow yang usianya paling tua.

Tabel 2.

Tingkat Penyusutan Kompos

\begin{tabular}{lc}
\hline \hline \multicolumn{1}{c}{ Rumah Kompos } & Penyusutan (\%) \\
\hline Bratang & 22,22 \\
Menur & 46,32 \\
Rungkut Asri & 20,41 \\
Tenggilis Utara & 11,70 \\
Tenggilis R. Taman & 23,81 \\
Rata-rata & 24,89 \\
\hline \hline
\end{tabular}

Pengukuran tingkat penyusutan kompos dilakukan di lima rumah kompos dikarenakan adanya tiga rumah kompos yang tidak beroperasi. Dari hasil perhitungan diperoleh tingkat penyusutan kompos untuk rumah kompos Bratang sebesar $22,22 \%$, tingkat penyusutan kompos untuk rumah kompos Menur sebesar 46,32\%, tingkat penyusutan kompos untuk rumah kompos Rungkut Asri sebesar 20,41\%, tingkat penyusutan kompos untuk rumah kompos Tenggilis Utara sebesar $11,70 \%$, dan tingkat penyusutan kompos untuk rumah kompos sebesar 23,81\%. Dari hasil perhitungan tersebut diambil tingkat penyusutan kompos rata-rata sebesar 24,89\% sebagai nilai generalisasi tingkat penyusutan kompos di rumah kompos Surabaya Timur.

\section{Material Balance Rumah Kompos di Surabaya Timur}

Pembuatan material balance ini melibatkan tiga skenario. Skenario pertama adalah material balance rumah kompos Surabaya Timur dengan delapan rumah kompos dan dua unit gasifikasi berfungsi serentak. Skenario kedua adalah material balance dengan lima rumah kompos dan dua unit gasifiaksi berfungsi serentak. Tiga rumah kompos yang tidak difungsikan adalah rumah kompos Liponsos, rumah kompos Wonorejo, dan rumah kompos Srikana. Skenario ketiga merupakan skenario tanpa reduksi sampah dan sampah langsung dikirim ke TPA. Perbandingan ketiga skenario tersebut dapat dilihat pada tabel 3 .

Tabel 3.

Perbandingan Skenario Rumah Kompos Surabaya Timur

\begin{tabular}{lccc}
\hline $\begin{array}{c}\text { Unit Pengelolaan } \\
\text { Sampah }\end{array}$ & Skenario 1 & $\begin{array}{c}\text { Skenario } \\
\text { Skenario 2 }\end{array}$ & Skenario 3 \\
\hline Rumah Kompos & 8 unit & 5 unit & - \\
Gasifikasi & 2 unit & 2 unit & - \\
TPA & residu kayu & $\begin{array}{c}\text { 5 rumah kompos } \\
\text { dan sampah }\end{array}$ & $\begin{array}{c}\text { Sampah tidak } \\
\text { terkelola dari 8 } \\
\end{array}$ \\
& & tidak terkelola & rum kompos \\
& dari 3 rumah & dan 2 \\
& & kompos & gasifikasi \\
\hline \hline
\end{tabular}

Pada skenario pertama sampah yang masuk ke rumah kompos di Surabaya Timur adalah 154919,28 kg. Sampah ini meliputi sampah hasil perantingan dan sampah pasar. Selanjutnya samaph yang masuk ini dipilah menjadi tiga jenis sampah yaitu sampah daun, sampah kayu, dan sampah pasar. Sampah kayu yang terbentuk sebesar 76654,04 kg. Sebesar $645 \mathrm{~kg}$ sampah kayu diolah dengan proses gasifikasi sedangkan sisanya sebesar 76309,04 kg dikirim ke TPA. Dari proses pemilahan diperoleh sampah daun sebesar $51487,11 \mathrm{~kg}$ dan sampah pasar sebesar 26778,13 kilogram sehingga total sampah yang digunakan sebagai bahan baku dalam proses

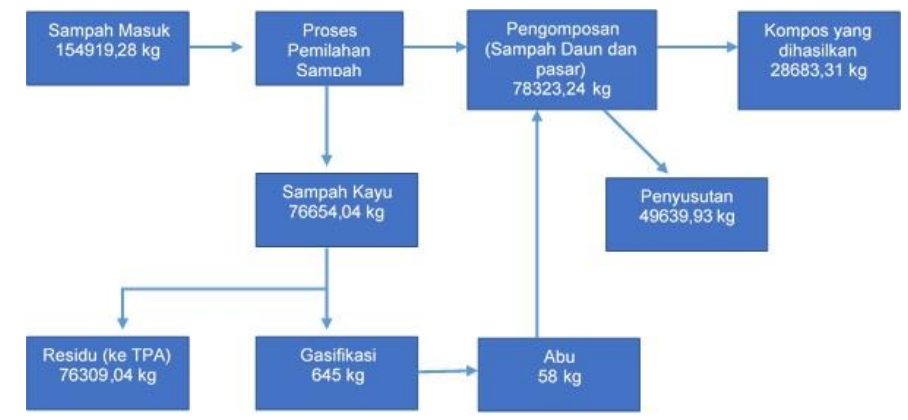

Gambar. 1. Diagram alir Material Balance skenario pertama

pengomposan adalah $78323,24 \mathrm{~kg}$. Kompos yang dihasilkan dari skenario pertama adalah sebesar $28683,31 \mathrm{~kg}$. Diagram 
alir material balance untuk skenario pertama dapat dilihat pada gambar 1.

Pada skenario kedua ini sampah yang masuk ke rumah kompos di Surabaya Timur adalah 154919,28 kg. Sampah ini meliputi sampah hasil perantingan dan sampah pasar. Dikarenakan adanya tiga rumah kompos yang tidak beroperasi menyebabkan adanya sampah yang tidak terolah sebesar $57993,43 \mathrm{~kg}$. Selanjutnya sampah yang masuk ini dipilah menjadi tiga jenis sampah yaitu sampah daun, sampah kayu, dan sampah pasar. Sampah kayu yang terbentuk sebesar $43837,72 \mathrm{~kg}$. Sebesar $645 \mathrm{~kg}$ sampah kayu diolah dengan proses gasifikasi sedangkan sisanya sebesar $43192,72 \mathrm{~kg}$ dikirim ke TPA. Dari proses pemilahan diperoleh sampah daun sebesar $29445 \mathrm{~kg}$ dan sampah pasar sebesar 23643,13 kilogram sehingga total sampah yang digunakan sebagai bahan baku dalam proses pengomposan adalah 53146,12 kg. Kompos yang dihasilkan dari skenario pertama adalah sebesar $97727,77 \mathrm{~kg}$. Diagram alir material balance untuk skenario pertama dapat dilihat pada gambar 2 .

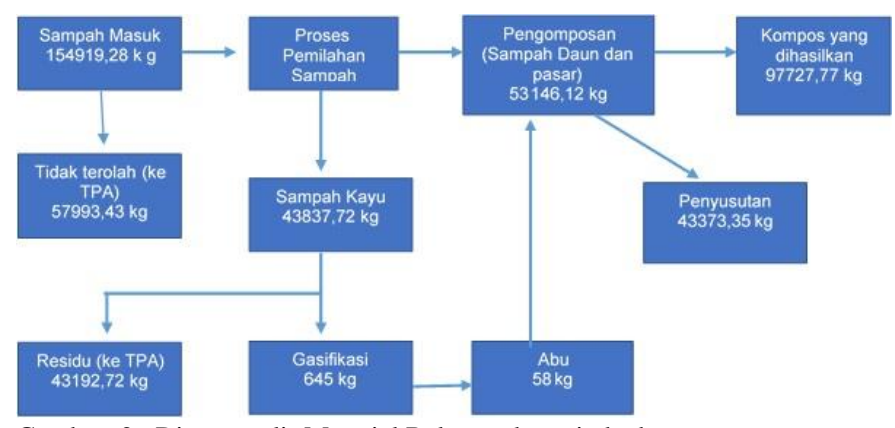

Gambar. 2. Diagram alir Material Balance skenario kedua

Pada skenario ketiga sampah daun dan kayu tidak direduksi melalui rumah kompos atau gasifikasi. Sampah yang dihasilkan langsung dikirim ke TPA. Pada skenario ketiga tidak memerlukan skema material balance karena seluruh sampah langsung dikirim ke TPA.

\section{Tingkat Reduksi}

Pada skenario pertama dimana delapan rumah kompos dan dua unit gasifikasi beroperasi melakukan proses reduksi sampah, rumah kompos di Surabaya Timur mampu mereduksi sampah sebesar 157175,48 $\mathrm{kg}$ setiap bulan dan menghasilkan reduksi sampah sebesar 50,74 \%. Pada skenario pertama jumlah total sampah yang tidak tereduksi dan dikirim ke TPA berjumllah sebesar 76309,04 kg setiap bulan. Sedangkan pada skenario kedua dimana hanya lima rumah kompos dan dua unit gasifikasi yang beroperasi melakukan proses reduksi sampah, rumah kompos Surabaya Timur mampu mereduksi 85857,38 kg sampah setiap bulan dan menghasilkan tingkat reduksi sebesar 34,68 \%. Jumlah sampah yang tidak terolah dan dikirim ke TPA berjumlah sebesar 101186,45 kg setiap bulan. Jumlah ini meningkat sebesar $24877,11 \mathrm{~kg}$ setiap bulannya jika dibandingkan dengan skenario pertama. Tingkat reduksi yang turun karena tidak beroperasinya tiga rumah kompos di Surabaya Timur diperoleh sebesar 16,06\%. Jumlah sampah tereduksi pada skenario kedua mengalami kenaikan sebesar
$71318,1 \mathrm{~kg}$ per bulan jika dibandingkan dengan jumlah sampah yang tereduksi pada skenario pertama. Pada skenario ketiga tingkat reduksi dianggap nol karena pada skenario ketiga seluruh sampah dikirim ke TPA.

Tabel 4.

Perbandingan Tingkat Reduksi

\begin{tabular}{|c|c|}
\hline Skenario & $\begin{array}{c}\text { Reduksi } \\
(\%)\end{array}$ \\
\hline 1 & 50,74 \\
\hline 2 & 34,68 \\
\hline 3 & 0,00 \\
\hline
\end{tabular}

\section{E. Perhitungan Emisi Gas Rumah Kaca}

Rumus perhitungan emisi gas rumah kaca pada proses pengomposan ada alah sebagai berikut:

- Emisi $\mathrm{CH}_{4}$

$$
\text { Emisi } \mathrm{CH}_{4}\left(\mathrm{GgCH}_{4}\right)=\Sigma(\mathrm{Mi} \times \mathrm{EFi}) \times 10^{-1}-\mathrm{R}(4)
$$

Keterangan :

Mi = massa sampah yang dikomposkan $(\mathrm{Gg})$

$\mathrm{EFi}$ = faktor emisi pada proses pengomposan $(\mathrm{g} \mathrm{CH} 4 / \mathrm{kg})$

$\mathrm{R}=$ jumlah recovery emisi $\mathrm{CH} 4(\mathrm{Gg} \mathrm{CH} 4)$

- Emisi $\mathrm{N}_{2} \mathrm{O}$

Emisi $\mathrm{N}_{2} \mathrm{O}\left(\mathrm{Gg} \mathrm{N}_{2} \mathrm{O}\right)=\Sigma(\mathrm{Mi} \times \mathrm{EFi}) \times 10^{-\mathrm{a}}$

Keterangan :

$\mathrm{Mi}$ = massa sampah yang dikomposkan $(\mathrm{Gg})$

$\mathrm{EFi}=$ faktor emisi pada proses pengomposan $(\mathrm{g} N 2 \mathrm{O} / \mathrm{kg})$

- Emisi $\mathrm{CO}_{2}$

Emisi $\mathrm{CO}_{2}=\frac{M r}{A r} \times C H W P$

$C H W P=\Sigma W i \times M \times D O C i$

Keterangan :

C HWP = Carbon Stock pada sampah yang masuk ke rumah kompos (Gg C/tahun)

Wi = Fraksi sampah i pada sampah yang masuk ke rumah kompos

$\mathrm{M}$ = massa total sampah yang masuk ke rumah kompos (Gg/tahun)

DOCi = nilai DOC untuk sampah jenis $\mathrm{i}$

$\mathrm{Mr} \quad=$ massa molekul relatif $\mathrm{CO}_{2}$ (44)

$\mathrm{Ar} \quad=$ massa atom relatif $\mathrm{C}(12)$

Sedangkan untuk mengukur emisi gas rumah kaca dari proses pembakaran di rumah kompos digunakan persamaan sebagai berikut:

$$
\text { Emisi } G R K_{a}=\text { Fuel }_{\alpha} \times E F_{a}
$$

Keterangan:

Fuel $_{\mathrm{a}}=$ konsumsi bahan bakar jenis a (TJ)

$\mathrm{EF}_{\mathrm{a}}=$ faktor emisi bahan bakar jenis a $(\mathrm{kg} / \mathrm{TJ})$

Rumus yang digunakan untuk menghitung emisi $\mathrm{CH}_{4}$ untuk sampah yang dikirim ke TPA dapat dilihat pada persamaan berikut ini. Sedangkan perhitungan emisi $\mathrm{CO}_{2}$ untuk sampah yang dikirim ke TPA menggunakan persamaan yang sama dengan sampah yang dikomposkan 
- Massa DOCi terdegradasi

$D D O C m i=W i \times D O C i \times D O C f \times M C F$

Keterangan:

DDOCmi $=$ massa DOC sampah i yang terdegradasi $(\mathrm{Gg})$

$\mathrm{Wi} \quad=$ massa sampah i yang terbuang $(\mathrm{Gg})$

DOCf $=$ DOC sampah jenis $\mathrm{i}$

$\mathrm{MCF}=$ Faktor koreksi metana

- Emisi $\mathrm{CH}_{4}$ Tiap Jenis Sampah

$L o=D D O C m i \times F \times \frac{16}{12}$

Keterangan:

Lo = potensi gas $\mathrm{CH} 4$ yang terbentuk $(\mathrm{Gg} \mathrm{CH} 4)$

$\mathrm{F} \quad$ =fraksi terbentuknya $\mathrm{CH}_{4}$ di landfill

$\frac{16}{12}=$ rasio berat molekul $\mathrm{CH}_{4} / \mathrm{C}$

- Total Emisi $\mathrm{CH}_{4}$

Emisi $\mathrm{CH}_{4}=\left(\mathrm{E} x \mathrm{Jumlah} \mathrm{CH}_{4} \mathrm{x}_{3} \mathrm{~T}-\mathrm{RT}\right) \times(1-\mathrm{OXT})(8)$

Keterangan:

Emisi $\mathrm{CH} 4=$ total emisi $\mathrm{CH}_{4}(\mathrm{Gg})$

$\mathrm{T}=$ tahun pembuangan sampah

$\mathrm{x} \quad=$ jenis sampah

RT = jumlah recovery $\mathrm{CH}_{4}(\mathrm{Gg})$

OXT = faktor oksidasi (fraksi)

\section{F. Perhitungan Emisi Gas Rumah Kaca Tiap Skenario}

Pada skenario pertama dengan delapan rumah kompos dan dua unit gasifikasi yang beroperasi menghasilkan 5408253,96 $\mathrm{kg} \mathrm{CO}, 14002,09 \mathrm{~kg} \mathrm{CH}_{4}$, dan $145,86 \mathrm{~kg} \mathrm{~N}_{2} \mathrm{O}$ yang setara dengan 5,80 $\mathrm{Gg} \mathrm{CO}_{2}$ per bulan. Pada skenario ini sampah yang terkirim ke TPA hanya berasal dari residu sampah kayu yang tidak terolah di unit rumah kompos mau di unit gasifikasi. Hasil perhitungan gas rumah kaca pada skenario satu dapat dilihat pada tabel 5 .

Tabel 5.

Emisi Gas Rumah Kaca pada Skenario Pertama

\begin{tabular}{|c|c|c|c|c|}
\hline \multirow{2}{*}{$\begin{array}{l}\text { Jenis } \\
\text { GRK }\end{array}$} & \multirow{2}{*}{$\begin{array}{c}\text { Jumlah Emisi } \\
\text { kg }\end{array}$} & \multirow{2}{*}{$\begin{array}{c}\text { Global } \\
\text { Warming } \\
\text { Potential } \\
(\text { GWP) }\end{array}$} & \multicolumn{2}{|c|}{ Jumlah Emisi } \\
\hline & & & $\operatorname{kg~CO} 2$ & $\mathrm{Gg} \mathrm{CO}_{2}$ \\
\hline $\mathrm{CO}_{2}$ & 5408253,96 & 1 & 5408253,96 & 5,40825396 \\
\hline $\mathrm{CH}_{4}$ & 14002,09 & 25 & 350052,33 & 0,350052334 \\
\hline $\mathrm{N}_{2} \mathrm{O}$ & 145,86 & 298 & 43466,51 & 0,043466509 \\
\hline Total & & & & 5,80 \\
\hline
\end{tabular}

Pada skenario kedua dengan lima rumah kompos yang beroperasi menghasilkan $4643335,56 \mathrm{~kg} \mathrm{CO}_{2}, 18053,41 \mathrm{~kg}$ $\mathrm{CH}_{4}$, dan $131,78 \mathrm{~kg} \mathrm{~N}_{2} \mathrm{O}$ yang setara dengan $5,13 \mathrm{Gg} \mathrm{CO}_{2}$ per bulan.

Dari hasil perhitungan dapat terlihat terdapat peningkatan emisi gas rumah kaca yang disebabkan bertambahnya jumlah sampah yang tidak terolah oleh rumah kompos dan harus dibuang ke TPA. Berbeda dengan skenario pertama kali ini sampah yang masuk TPA meliputi sampah daun, sampah kayu, dan sampah pasar. Hasil perhitungan gas rumah kaca pada skenario kedua dapat dilihat pada tabel 6 .

Pada skenario ketiga ini seluruh sampah yang seharusnya diolah melalui proses pengomposan di rumah kompos tidak diolah di rumah kompos, namun langsung dikirim ke TPA. Perhitungan emisi gas rumah kaca pada skenario ketiga ini hanya menghitung emisi gas rumah kaca yang dihasilkan dari aktifitas penimbunan sampah di TPA.

Tabel 6.

Emisi Gas Rumah Kaca pada Skenario Kedua

\begin{tabular}{lcccc}
\hline \hline Jenis & Jumlah Emisi & $\begin{array}{c}\text { Global } \\
\text { Warming } \\
\text { Potential } \\
(\mathbf{G W P})\end{array}$ & $\mathbf{k}$ kg CO & $\mathbf{G g ~ C O}_{2}$ \\
\hline $\mathrm{CO}_{2}$ & $\mathbf{k g}$ & 1 & 4643335,56 & 4,643336 \\
$\mathrm{CH}_{4}$ & 18053335,56 & 25 & 451335,29 & 0,451335 \\
$\mathrm{~N}_{2} \mathrm{O}$ & 131,78 & 298 & 39271,76 & 0,039272 \\
Total & & & & 5,13 \\
\hline \hline
\end{tabular}

Perhitungan pada skenario ketiga ini menggunakan asumsi tidak ada metana yang di recovery dari TPA dan diasumsikan tidak terkelola (TPA tidak tertutup bahan yang mampu membantu proses aerasi) sehingga faktor oksidasinya nol. Tabel 7.

Emisi Gas Rumah Kaca pada Skenario Ketiga

\begin{tabular}{rlcccc}
\hline \hline Jenis & $\begin{array}{l}\text { Jumlah } \\
\text { GRK }\end{array}$ & kmisi & $\begin{array}{c}\text { Global } \\
\text { Warming } \\
\text { Potential } \\
\text { (GWP) }\end{array}$ & & \multicolumn{2}{c}{ Jumlah Emisi } \\
\hline $\mathrm{CO}_{2}$ & 173343,05 & 1 & 173343,05 & 0,17334 \\
$\mathrm{CH}_{4}$ & 12606,77 & 25 & 315169,18 & 0,31517
\end{tabular}

Total

Pada skenario ketiga ini hasil perhitungan gas rumah kaca yang diperoleh adalah $\mathrm{CO}_{2}$ sebesar $173343,05 \mathrm{~kg}$ dan $\mathrm{CH}_{4}$ sebesar $12606,77 \mathrm{~kg}$. Jumlah tersebut setara dengan $0,49 \mathrm{Gg}$ $\mathrm{CO}_{2}$ per bulan.

Emisi gas rumah kaca yang dihasilkan pada skenario ketiga menunjukkan angka yang jauh lebih kecil dibandingkan dengan emisi gas rumah kaca yang dihasilkan dari proses pengomposan. Hal ini disebabkan karena sebenarnya penyumbang emisi gas rumah kaca terbesar dari proses pengomposan tersebut berasal dari proses pembakaran.

Dari hasil perhitungan tersebut terlihat bahwa gas rumah kaca yang dihasilkan dari skenario pertama lebih tinggi yaitu $5,80 \mathrm{Gg} \mathrm{CO}_{2}$ perbulan, sedangkan emisi gas rumah kaca dari skenario kedua sebesar $5,13 \mathrm{Gg} \mathrm{CO} \mathrm{CO}_{2}$ per bulan. Hal ini disebabkan pada skenario pertama jumlah alat pencacah yang dioperasikan lebih banyak sehingga menyebabkan penggunaan bahan bakar meningkat. Kenaikan penggunaan bahan bakar akan menyebabkan kenaikan pada emisi gas rumah kaca yang dihasilkan. 


\section{KESIMPULAN}

Berdasarkan hasil analisis dan pembahasan, diperoleh kesimpulan sebagai berikut:

1) Massa timbulan sampah yang masuk ke rumah kompos Surabaya Timur adalah sebesar $51487,11 \mathrm{~kg}$ per bulan untuk sampah daun, 76654,04 kg per bulan untuk sampah kayu, dan 26778,13 kg per bulan untuk sampah pasar.

2) Dari hasil perhitungan material balance diperoleh tingkat reduksi sebesar 50,74\% untuk skenario pertama perhitungan dan tingkat reduksi sebesar 34,68 \% untuk perhitungan skenario kedua. Diantara kedua skenario terdapat selisih tingkat reduksi sebesar 16,06\% yang disebabkan tidak berfungsinya tiga rumah kompos di Surabaya Timur.

3) Dari hasil perhitungan emisi gas rumah kaca dengan metode IPCC diperoleh emisi gas rumah kaca sebesar 5,80 Gg CO2 per bulan untuk skenario pertama, emisi gas rumah kaca sebesar 5,13 Gg CO2 per bulan untuk skenario kedua, dan emisi gas rumah kaca sebesar 0,49 $\mathrm{Gg} \mathrm{CO} 2$ per bulan untuk skenario ketiga.

\section{DAFTAR PUSTAKA}

[1] Hadiwiyoto, S, 1993. Teknologi Pengolahan Hasil Perikanan. Penerbit Liberty, Yogyakarta.

[2] Umarie, W. I. 2012. Potensi pencemaran lingkungan dari pengolahan sampah di rumah kompos Surabaya Timur. Institut Teknologi Sepuluh Nopember Surabaya.

[3] Jensen, J.E.F. and Pipatti. 1996. Chapter 5 - Waste, In 'IPCC Good Practice Guidance and Uncertainty Management in National Greenhouse Gas Inventories'. Intergovernmental Panel on Climate Change, National Greenhouse Gas Inventory programme.

[4] Djajadilaga, Maulani., Tejalaksana, Aksa., Harnowo, Heru., Gusthi, Agnes Swastikarina., Sudarmanto. 2009. Emisi Gas Rumah Kaca dalam Angka. Kementerian Lingkungan Hidup.

[5] He, Y., Inamori, Y., Mizuochi, M., Kong, H., Iwami, N., and Sun, T. 2001. Nitrous oxide emissions from aerated composting of organic waste. Environ Sci Technol 35: 2347-2351. 